\title{
AUGUSTUS HARDIN BEAUMONT: ANGLO-AMERICAN RADICAL (1798-I838)*
}

Augustus Hardin Beaumont is known as a secondary figure of English radicalism during the $1830 \mathrm{~s}$. He came to England from Jamaica in the spring of 1835 and by the end of January 1838 he was dead. He was briefly associated with the London Working Men's Association in its early stages and then went to the Northeast where he founded the Northern Liberator. Historians of Chartism have noted him in passing and they have recognized his almost frenzied militancy in support of democratic reform. Most agree with Francis Place's judgment that "his eccentricities sometimes bordered upon insanity", 1 but beyond that they tell us little more about him.

In fact, closer examination of his life shows him to be a far more interesting figure than at first glance he appears. Beaumont was American by birth, Jamaican by rearing, and English by adoption. $\mathrm{He}$ had an extensive and financially profitable journalistic career in Jamaica, where he became a generally respected public official and spokesman for the planter interest while at the same time supporting colonial reforms. Through an older brother he became involved in continental European revolutionary movements and subsequently changed from being an apologist to a critic of colonial slavery. At the same time he became an outspoken advocate of democratic institutions. This unpopular position undid his Jamaican reputation and forced him to come to England where he launched a career as a radical journalist. After an undistinguished beginning he eventually achieved prominence as the catalyst of a militant working class movement in northeastern England. By the time of his death he had participated in the reform movements of four countries - Jamaica, England, France, and Belgium - possibly had fought in a fifth, Spain, and at the last was preparing to embark to join a rebellion in a sixth, Canada. This more complete picture of the man can be pieced together from sources

* The author wishes to acknowledge with gratitude the support of the American Philosophical Society and the Faculty Research Committee of the University of Oklahoma in the research for this paper.

1 Francis Place Manuscript Collection, British Museum, London, Additional Manuscripts 27819, f. 32. Place Collection cited hereafter by Add. Mss. number. 
that have hitherto been disparate. They include statements by contemporaries who knew him, various pamphlets of Beaumont's, and the several newspapers which he published. Most important, a series of obituary articles appeared in the Northern Liberator following his death which give an extensive account of his early life before coming to England. ${ }^{1}$

Beaumont was born in New York City on August 29, 1798. His father was a doctor and had been on the staff of the British army during the war of the American Revolution. His mother was an Irish woman whose maiden name was McGowan. Augustus had two brothers, an older one named Arthur James and a younger named Edmund Hardin. The boys were orphaned early. Their mother died when Augustus was five and their father, who was an alcoholic, followed soon after. Their American life ended when they were sent to the care of a maternal aunt, Mrs Hardin, in Jamaica. In spite of this childhood departure both Augustus and his older brother Arthur continued to think of themselves as Americans in later years and on numerous occasions in their political careers described themselves as such, idealizing the political conditions of the United States in contrast to Europe.

Augustus fared less well than his brothers under the care of his aunt and his acute resentment of authority through the rest of his life may have begun with her. According to his obituary he was frequently severely punished to please his younger brother who was more favored. Later both Arthur and Edmund were regarded to have more talent than Augustus and were sent to university in Great Britain. Arthur, who went to Oxford, matriculated in Queen's College in 1821 and took a degree in $1825 .^{2}$ Edmund was sent to Edinburgh, where he matriculated as a medical student in 1821,1822, and 1824, but did not take a degree. ${ }^{3}$ Augustus was kept back to be apprenticed as a planter

1 Northern Liberator, April 21, 28, and May 5, 1838. In part the details of these articles can be corroborated from testimony by Beaumont to Sir George Grey's select committee on Negro apprenticeship in 1836 (Great Britain, Parliament, House of Commons, Sessional Papers, 1836, XV, pp. 224-79).

2 Joseph Foster, Alumni Oxonienses: the Members of the University of Oxford, 1715-1886 (London, 1887-88), I, p. 83.

3 Letter from the Keeper of Manuscripts, Edinburgh University Library, January 16, 1969. Edmund appears later to have become a tailor and a printer. $\mathrm{He}$ has been discovered in a directory listing for 1830-33 as "Beaumont \& Holt, tailors, clothiers, outfitters", and in 1831 he declared a printing press at St Michael's Alley, Cornhill. Augustus Beaumont witnessed the declaration. (I am indebted to Professor William B. Todd, Department of English, The University of Texas at Austin for this information.) Several of the later pamphlets of Arthur and Augustus Beaumont carried a printer's mark which read "Edmund Beaumont, Printer, St. Michael's Alley, Cornhill". 
when he was eighteen. He bridled at the preference shown to his brothers and plunged into a program of self-education through reading. By his twentieth year his ambition and dissatisfaction with the socially inferior role of overseer had led him to become a lawyer's clerk in Kingston.

About this time an incident occurred which was illustrative of many later protests of Beaumont's. He was present at the hanging of a colored woman who had been convicted of beating a child to death. The execution was in conflict with the island's color caste laws in that the executioner was a black man and the crowd protested. Beaumont joined them when they intervened to prevent the act from being carried out and he was arrested for his trouble. The woman was eventually hanged, but Beaumont was jailed for sixteen days before he was bailed, allegedly under conditions which impaired his health permanently. Later Beaumont brought an action against the deputy marshal for negligence in not providing him with a copy of the warrant under which he was arrested. In this case, as often later, Beaumont had become outraged at an injustice to someone with whom he was not directly associated. The grievance was more technical than substantial, since the woman's crime does not appear to have been in dispute. When he was apprehended by the authorities, his counterattack again was on technical grounds, as were so many of his criticisms of authority in his later writings. He pleaded his own case against the deputy marshal and happily won a judgment against him for $£ 140$.

The episode appears to have been of great importance in shaping Beaumont's subsequent career. Judging from the prominence given it in his obituary, and by implication in recollections Beaumont must have made to his associates before his death, it seems to have "strengthened and confirmed that hatred of oppression, and that determination to oppose it in every form, which was the characteristic of his life." 1 At least as important, the judgment he won enabled him to begin a career as a journalist.

Beaumont established The Trifler in December 1822. The paper was as insignificant as its name implies and it lasted only a few months. It consisted of critical letters over pseudonymous signatures such as Cincinnatus, Toleratio, Verax, and Fum Fum Foofoo. The letters showed little social concern but chiefly attacked public officials, especially the Duke of Manchester, the governor of the island. By spring 1823 the paper's outspokenness had provoked three libel actions against Beaumont, and The Trifler ceased publication on June 21st. He was tried on only one charge, an attack upon Manchester, in

1 Northern Liberator, April 21, 1838. 
August 1823 and again he conducted his own case. His defense won him acquittal and established him as a young man of promise.

In September 1823 after his acquittal Beaumont began another paper, a daily, under the title of Public Advertiser. He operated it successfully until October 1826 when he combined it with a hitherto rival, The Courant, under the new title of Jamaica Courant and Public Advertiser. This paper continued under his sole proprietorship until December 31, 1831.

The Public Advertiser and later the Courant made Beaumont's reputation on the island. Over the next several years he came as close as at any time in his life to being part of an Establishment and before long he kregan to be called upon for public service by the planting interest. In January 1826 he was sent to England by his fellow colonists on an unspecified mission to Mr Canning, although it is likely that it was connected with the question of slavery emancipation. While he was in London, Beaumont published a pamphlet arguing the case for compensation for slave owners. He made no attempt to question the injustice of slavery, but he argued "that the Crime of holding their Fellow men in Slavery originated with the British Nation", and that "the expense of undoing a great National wrong should be borne by the whole - not by a part - and that part not the most guilty." ${ }^{1} \mathrm{He}$ called for a definite commitment to compensation at a fair level from a fund established for that purpose and urged that compensation be paid progressively with each amelioration in the slaves' condition which reduced their value to their owners. Beaumont's pamphlet had a wide sale in England where it went through at least four editions, and Jamaicans in the districts of Manchester, Clarendon, and Vire were so grateful for his efforts that they presented him with an inscribed silver vase.

Beaumont continued to be a moderate representative of the planters' interest against English abolitionist pressure for the next several years. He never defended slavery as an institution, but he cautioned against the unpredictable effects of sudden emancipation and maintained his demand for compensation. Upon his return from England he published the next of the Consolidated Slave Law of 1826 with notations. ${ }^{2}$ Subsequently he published the Jamaican slave law in London along with supporting documents. In an introduction he argued:

1 Compensation to Slave Owners Fairly Considered in an Appeal to the Common Sense of the People of England, 4th ed. (London, 1826), p. 5.

2 The Consolidated Slave Law Passed the 22d December $1826 \ldots$, 2nd ed. (Kingston, Jamaica, 1827). 
"the claim of the colonists who bought [the slave], and of the capitalist who lent money on him as property, cannot be disputed by the Sovereign legislature, which solemnly invited and legalized these proceedings; and so became bound to continue its protection to such property, or on withholding it, to grant indemnification."1

During these years the Courant became identified as a spokesman for the planting interest. Beaumont played a major role in fomenting a persecution against sectarian missionaries who were suspected of arousing slaves to expect emancipation in the late $1820 \mathrm{~s}^{2}$

As his reputation grew Beaumont began to take part in colonial politics. In July 1827 he was elected a Common Councilman for Kingston. Later in the autumn he offered himself for a colonial Assembly seat from St Elizabeth's. Beaumont's fiery disposition came through in the contest. The retiring member, the attorney general of the island, so disliked the thought of Beaumont succeeding him that he stood again and kept the seat. This provoked actions by Beaumont that led to two more legal proceedings, one for statements which appeared in the Courant and another criminal action for challenging his opponent to a duel. Both resulted in acquittals. Beaumont stood again for the Assembly from Kingston in May 1829, but lost narrowly to an old and respected member. He finally won a seat from the parish of Westmoreland in August 1829. He sat only a short time, however, for the next year in April health and the strain of his editorship caused him to travel to England. There he was elected a member of the West India Association and played a prominent part in its affairs.

Beaumont's commitment to radical politics crystallized between 1830 and 1832. He had been a frequent critic of policies and politicians from his early days on The Trifler; his altercation with the attorney general in 1827 was only another chapter in that story. Further he often had acted to change existing practices. As a magistrate he granted the first license to a black man to preach in Jamaica. Later as an assembly-man he played a prominent role in securing removal of Jewish disabilities, in recognition for which the Jews voted him thanks and gave him a silver vase. But it was experiences which began with his trip to Europe in 1830 and culminated in the Jamaican slave revolt of December 1831 that turned him into a radical activist.

\footnotetext{
1 Slave Law of Jamaica with Proceedings and Documents Relative Thereto (London, 1828), pp. ix-x.

2 Philip D. Curtin, Two Jamaicas: the Role of Ideas in a Tropical Colony, 1830-1865 (Cambridge, Mass., 1955), pp. 57-58; William Laurence Burn, Emancipation and Apprenticeship in the British West Indies (London, 1937), pp. 94-95.
} 
The author of his obituary stated "it is certain that enlarged sentiments and noble aspirations for freedom of universal humanity were demonstrated in him from the moment of his planting his foot on English ground." 1 More precisely he seems to have come under the influence of his older brother Arthur James. This man already had a well-developed interest in European radical movements. Together the two brothers went off to Paris soon after the July Revolution and joined the National Guard. But they quickly departed for the more exciting scenes of "the Revolution then progressing" in Brussels. They recalled their American origins and in a later pamphlet describing their adventures said they "wished to return to Lafayette their portion of the debt which every American owes that Patriarch of Liberty and which each friend of the rights of man can only liquidate by doing all he can for the same cause - the benefit of the whole human race."2 They arrived in the midst of fighting in the city and soon joined the rebels in the streets. Arthur was severely wounded in the leg while Augustus received minor injuries which were not disabling. Augustus experienced considerable danger fighting with the rebel commander Van Halem and received from him a testimonial for his bravery later.

These exhilarating events doubtless roused Beaumont's radicalism, but they did not cause him to abandon past positions immediately. His views showed some ambivalence after his return to Jamaica in August 1831. Westmoreland re-elected him to its seat in the Assembly and he soon authored an officially subsidized pamphlet defending Jamaican interests against legislation form London. ${ }^{3}$ Beaumont set his argument against the growing agitation for parliamentary reform and slavery emancipation in England. He warned that Jamaica would go the way the American colonies did in 1775 unless she was awarded formal representation in the House of Commons to compensate for the loss of the informal pre-reform West Indian voice or she was granted total independence. As earlier and like most contemporary defenders of the Jamaican position, he decried slavery as an evil, but he claimed the Jamaican legislature would be most effective in ameliorating and eventually eliminating it. $\mathrm{He}$ charged that earlier English governments had forced slavery on an unwilling Jamaica and denied that an alien

\footnotetext{
1 Northern Liberator, April 28, 1838.

2 Adventures of Two Americans in the Siege of Paris, September 1830 (London, $1830)$, p. 3. The precise authorship of this pamphlet is not clear since the title page says only "by one of them".

3 The Jamaica Petition for Representation in the British House of Commons or Independence (London, 1831). For the Jamaican Assembly subsidy of the pamphlet, see Curtin, p. 63, n. 4.
} 
parliament now had a right to reverse itself and force emancipation.

By this time expectation was high that emancipation would come shortly, particularly if parliament were reformed in England. Controversy raged among Jamaicans over the wisdom of emancipation, while during the autumn rumors raced through the slave quarters that an order for their liberation was on the way. Beaumont's Courant, in keeping with its earlier sympathy with the planters, published reports of their discussions and resolutions on emancipation. At the same time it repeated a rumor that the British garrison on the island had received "secret orders to remain neuter or to go against us in the event of disturbance." 1 Then on November 2,1831, Beaumont seemed to shift from his earlier support to the planter interest by joining with a reforming colleague, Francis Watkis of Kingston, to propose motions for compulsory manumission and to prohibit flogging of female slaves. Both motions failed overwhelmingly, but this along with the Courant statement led to later accusations that Beaumont had encouraged the slaves to rebel. Rebellion broke out on December 27th. During the rising Beaumont acted in support of authority. He expressed contempt for the official militia and organized an irregular force he called the Cornwall Rangers, which he used to win the surrender of many hundreds of slaves on the promise of free pardon. ${ }^{2}$

The slave rebellion both marked the turning point in Beaumont's Jamaican fortunes and confirmed him for the future as a radical reformer. He transferred ownership of the Jamaica Courant and Public Advertiser at the end of 1831, but allowed the new owner to defer payment until the following year. In the meantime Beaumont came under attack from the planters for allegedly abetting the rebellion. The newspaper joined in the attack in its columns, urging Beaumont's debtors not to repay their obligations to him "because his politics were inimical to the planting interest". ${ }^{3}$ Subsequently the new owner destroyed records of money owed to Beaumont and then went bankrupt himself without having paid for the paper. In the midst of these reverses Beaumont married, but this new obligation did not deter him from further political and journalistic activity. He proposed a bill in the colonial assembly in 1833 for immediate emancipation instead of the government's apprenticeship proposal. When it failed he resigned his seat. The following October he began a democratic newspaper called The Isonomist. It lasted only until January 31,1834 , but it was long

1 William Law Mathieson, British Slavery and Its Abolition, 1823-1838 (London, 1926), p. 208.

2 Ibid., p. 214; Northern Liberator, April 28, 1838.

3 Northern Liberator, April 28, 1838. 
enough for Beaumont's articles to provoke yet another prosecution by the colonial government. ${ }^{1}$

Beaumont gives the impression of having been a querulous, abrasive man, subject to quick and extreme anger. Not only did he incur official censure on several occasions. He also fought thirteen duels during his public career. One of these, involving a challenge over the proper guardianship of a young colored woman, resulted in a fatality. This penchant for quick and disproportionate anger remained with him, as can be seen from the outrage he felt at being addressed as "Mr" instead of "Esquire" shortly before his death. ${ }^{2}$ He became unpopular with the planting interest and his position became progressively more difficult. His last fifteen months in Jamaica are obscure, but he was thinking of leaving the island and on May 5, 1835, he and his wife departed for England.

His first task when he arrived in England was to take up the defense of his brother. After the revolutionary events of 1830, Arthur Beaumont had become involved with French radical groups and had fallen afoul of the royal authorities there. He was condemned to a month's imprisonment in March 1832 for "seeking to bring into hatred and contempt the Government of the King" by publishing the preceding autumn a pamphlet called The Society of the Friends of the People. Subsequently on appeal he was acquitted. During this period Arthur also published $D e$ la constitution américaine, et de quelques calomnies dont elle a été l'objet de nos jours, ${ }^{3}$ and An American's Defence of His Government, in an appeal to the common sense of the nations of Europe. ${ }^{4}$ More seriously he became treasurer and member of the central committee of the democratic republican group called the Societe des droits de l'homme. The society was involved in street riots of April 1834 and its members including Beaumont were arrested. They were held for a long period and finally tried beginning in May 1835 by the Chamber of Peers.

Augustus devoted himself initially to securing the release of his brother and, when that proved unsuccessful, to providing for his defense in the trial. He appealed for assistance both to Lord Palmerston and the British ambassador in Paris, pleading variously that his

\footnotetext{
${ }_{1}^{1}$ Beaumont lost this prosecution, which involved contempt for the colonial Assembly, on appeal to the Privy Council in London. The Privy Council decided against Beaumont without costs and upheld the Assembly in punishing a contempt by publication of a libel (Burn, p. 190, n. 3).

2 Northern Liberator, October 27, November 25, 1837.

3 (Paris, 1831).

4 (London, 1831.)
} 
brother as a British subject was not subject to French law (a claim complicated by his American birth), that no French law covered the offense at the time it was committed, and that his brother was subjected to inhumane treatment. The Foreign Office responded courteously but ineffectively to his letters, while Beaumont became increasingly acrid and technical in his arguments. When he published one of his letters before sending it, Palmerston broke off the exchange. During these transactions, Augustus made at least two trips to visit his brother in Paris. Arthur was eventually convicted with a number of others and sentenced to transportation in January $1836 .{ }^{1}$

After the sentence, Augustus returried to London to found a newspaper called The Radical. He announced it was "devoted to democracy and therefore to the true interest of the people", and he summarized its political creed as "Freedom of the Press and Universal Suffrage". Nevertheless he expected to use it to exert pressure on the British government to secure his brother's release. He succeeded in generating some interest in the case, not only in London but also in Norwich and Glasgow, to the point that a petition to the House of Commons was adopted at several public meetings. At the same time Beaumont made The Radical a forum for issues of general working class appeal and he demonstrated his considerable talents as a political journalist. The paper survived only a few weeks before Beaumont had to terminate it at a considerable loss. ${ }^{2}$

Beaumont's experience with The Radical brought him into contact with a number of working class leaders and groups, but he failed to win the recognition as a leader that his personality craved. Place thought he "meant well to the working people at all times, even when his actions were most likely to be injurious to them", and found him one of those who were misguided and disruptive "in their eagerness to become notorious - popular - as they believed". ${ }^{3}$ He had become involved with the movement for an unstamped press and release of the Dorchester labourers while The Radical was still publishing. In summer

1 For details see Augustus H. Beaumont, Ambassadors: What Do We Pay Them For? A Question for the People (London, 1836). See also Add. Mss. 27819, ff. 218-19.

2 Add. Mss. 27820, f. 12. The paper published from March 13 to July 17, 1836. Beaumont's ability to sustain this loss but to continue to maintain a Lordon residence and his political activities, as well as start another newspaper in 1837 , suggests that he brought considerable resources with him from Jamaica despite his losses there.

${ }^{8}$ Add. Mss. 27819, f. 32. The chief source for this period of Beaumont's life is Francis Place's narrative account of the period. It is not completely satisfactory for despite his approval of Beaumont's motives, Place thought him unbalanced and was often harshly critical. 
1836 he differed with the group trying to establish the London Working Men's Association and joined Feargus O'Connor and others to set up a rival organization called the Universal Suffrage Club. ${ }^{1}$ By autumn, however, Beaumont had quarreled with O'Connor and was sufficiently reconciled to the Working Men's Association to translate an address from it to the "Working Classes of Belgium". ${ }^{2}$

Following this Beaumont disappeared for a time. Place reports that about the middle of November he abandoned his efforts to secure the release of his brother, after which Place took up the case through Joseph Hume as an intermediary. A correspondence ensued from November 1836 to March 1837 which Place implies facilitated the release of Arthur Beaumont in June 1837. ${ }^{3}$ Place also alludes to a visit of Augustus Beaumont to Spain during which he joined the British legion and frequently volunteered for dangerous assignments. He does not date these experiences but discusses them as if they occurred in late 1836 or early 1837.4 When Augustus returned from Spain he toured extensively in the northern counties of England and southern Scotland. He enjoyed much greater success than he had had in London and was impressed by what he perceived to be the more revolutionary quality of the men of the north. Even Place conceded that "by his address, his energy, decision and fluency of speech [Beaumont] soon caused himself to be acknowledged as a leader of the working people." 5 During this tour he visited Newcastle upon Tyne and opened the last and most influential phase of his political career.

A newly formed Newcastle Working Men's Association invited him to stand for Newcastle in the election following the death of William IV. How Beaumont came to be invited is not clear. The local leaders were acquainted with a number of major figures, any of whom could have suggested his name. O'Connor and John Bell of the True Sun, for instance, knew Beaumont and both had visited the town during the preceding year. It may have been coincidental that Beaumont's northern tour took him to Newcastle just as the association wanted a candidate. There was even a suggestion that they thought they were inviting Arthur James Beaumont, a circumstance which was entirely possible since they had recently exchanged addresses with him at the

1 Add. Mss. 27819, ff. 33-34. Place suggested they made two attempts at rival organization, one called the Universal Suffrage Club and the other the Central Committee of the Metropolitan Radical Unions. In fact, the Central Committee was a device for calling a meeting which resulted in the formation of the Universal Suffrage Club. The Club then continued to meet into the autumn (The Radical, June 12, 1836; London Mercury, September 18, 1836).

2 Add. Mss. 27819, f. 45.

4 Add. Mss. 27820, ff. 11-12.

3 Add. Mss. 27819, ff. 218-19.

5 Ibid. 
time of his release. ${ }^{1}$ In any case, it was Augustus who arrived on July 23rd with his wife and he immediately issued an address.

Beaumont's contest was marked by two things, the radicalness of his own proposals and the rapidity with which the town's ranks closed against him. He proposed to provide full employment at reasonable wages by nationalization of railways, canals and other large public works, so that "any man who was turned off work elsewhere might apply to the national and comprehensive company with a certainty of success." 2 When they read this, the town's Whigs became so alarmed that he might capture one of the two seats that they hurriedly brought forward a second candidate to stand alongside the Whig and two Tories who had already announced. Beaumont won the show of hands at the nomination but he came at the bottom of the poll with 290 votes, 800 fewer than his nearest rival. Nevertheless, on the strength of the show of hands, he allowed himself to be drawn victoriously through the streets accompanied by a somewhat unruly crowd. ${ }^{3}$

Despite his rebuff in the Newcastle election, Beaumont developed a liking for the place. His decision to stay on over the next several months had immense importance for the development of the working class movement there. For some time various local leaders had striven to bring together an energetic organization but had been held back by the same problems of personality and policy that hampered the London association at its outset. Beaumont's extraordinarily forceful, if unstable, personality provided the necessary catalyst to mobilize the latent potential of working class sentiment there. He more than anyone else gave it the necessary push to get moving, and although it faltered after his death, it continued in being until it joined with the national Chartist movement the next year. Above all, he injected a near revolutionary militancy that appealed to many northeastern radicals and long outlived him.

After his unsuccessful election contest, Beaumont pledged himself to organize working men's associations all over the kingdom to achieve reform. He threw himself into this activity and during the autumn began building up a network of associations in the towns and villages throughout the northeastern region. He urged on his listeners that the time was ripe, as when he told a group of Winlaton ironworkers, "Now

${ }^{1}$ Newcastle Chronicle, July 29, 1837.

2 Newcastle Courant, July 28, 1837. Beaumont also had developed ideas for land nationalization in a June newspaper article but he returned to neither of these ideas later. Place noted at the bottom of the June article "Poor Crazy A. H. Beaumont" (Place Newscutting Collection, British Museum, Set $¥ 56$, ff. 90-92).

3 Newcastle Chronicle, July 29, 1837. 
is the time for the working classes to unite in order to achieve their freedom; if you omit this opportunity, years of darkness and sanguinary warfare may succeed." 1 His work also brought him into contact with groups in Sunderland and South Shields which had organized spontaneously and he began establishing contacts that eventually created a regional rather than a series of purely local movements of Chartism in the Northeast.

One of Beaumont's most important acts was to give the Northeast a radical newspaper. Earlier efforts to get one going had failed repeatedly in spite of long standing interest. Only when Beaumont moved the equipment from the defunct Radical north and launched the Northern Liberator did a radical paper publish with any longevity. The first issue appeared on October 21, 1837; the last on December 19, $1840 .{ }^{2}$ The opening leader proclaimed "The Northern Liberator is published for the express purpose of maintaining pure democracy in the North of England." The goal of universal suffrage as the prerequisite to all other goals remained Beaumont's main objective as long as he directed the paper.

There can be no doubt that the Northern Liberator enhanced radical solidarity in the region. It printed news and articles from other regions on matters of working class interest. It provided a link between working class groups of the Northeast and by doing so, gave Newcastle an ascendancy over them. It informed readers of local activities rarely reported in other papers, and it printed full and sympathetic reports of meetings which could be read all over the district. Robert Lowery told a South Shields meeting that the Liberator provided them with a paper which "would do justice to working men", 3 and frequently meetings ended with three cheers for Beaumont or the Liberator.

Beaumont's choice of issues to feature in the columns of the paper largely determined the content of working class agitation over the next several months. He managed to arouse great concern over the rebellion in Canada, the case of the Glasgow cotton spinners, and the "finality" declaration of Lord John Russell. Beaumont indicated the militancy he tried to impart to the district when he said of Russell's statement, "He was not an advocate of revolution if the principle of the constitution could be fairly reduced to practice without it; but he would welcome civil war rather than base slavery to the doctrine of Lord John Russell." 4 He also attacked the implementation of the new Poor Law with great vigor.

1 Northern Liberator, November 4, 1837.

2 The paper combined with The Champion of London as the Northern Liberator and Champion beginning May 30, 1840.

3 Northern Liberator, October 28, 1837.

4 Ibid., December 9, 1837. 
The campaign over the last led to the great New Year's Day antiPoor Law meeting on the Newcastle Town Moor at which Joseph Rayner Stephens made the vehement speech so frequently quoted by historians of the period. Less well known were the speeches of other prominent working class radicals, such as $\mathrm{Dr}$ John Taylor, J. P. Cobbett, and Feargus $\mathrm{O}^{\prime}$ Connor, who probably responded to invitations because of their old acquaintance with Beaumont. This meeting held out promise of becoming the basis of a united regional working class organization, for the conditions were ready for bringing together the various local organizations that had developed with Beaumont's encouragement in the autumn. A committee representing the "United Working Men's Associations of the North" planned the demonstration and could have been the basis for future joint action. Had Beaumont remained in the district the union might have been achieved through his efforts, but New Year's Day was his last public appearance in the Northeast.

The Canadian rebellion was a question very close to Beaumont's heart, perhaps because of his own experience in the colonies. By the end of 1837 it had become the issue which dominated his attention. In Newcastle on January 1,1838 , he announced plans to leave the town to go to Canada, and one man who knew him said he planned to raise a group of five hundred men to support the rebels. ${ }^{1}$ That he was sincere about leaving is clear from his sale on the same day of the Northern Liberator to Robert Blakey of Morpeth for $£ 500 .^{2}$ He left shortly to speak on the Canadian rebellion at meetings in Scotland and then appeared on January 8th and 9th in Leeds. At the second meeting he worked himself into an uncontrollable rage of debate with another speaker, after which he hurried in an overheated condition to take an outside seat on the coach to London. ${ }^{3}$ The exposure of the journey led to an illness and by the end of the month he was dead.

Beaumont's memory was honored long afterward in the Northeast. Place's comments indicate this was not always true elsewhere. These contrasting reactions tell us a lot about Beaumont's fate. He had great capacity to move men by speech and the printed word. This facility was marred by an emotional intensity and lack of proportion which at the same time may have been part of his appeal in a period of

1 Thomas Ainge Devyr, Odd Book of the Nineteenth Century (Greenpoint, $\mathrm{N}$. Y., 1882), p. 159.

${ }^{2}$ Henry Miller, ed., The Memoirs of Dr. Robert Blakey (London, 1879), p. 108. Place claimed that by this time Beaumont was in severe financial straits and accounts for the sale in that way (Add. Mss. 27820, f. 13).

3 Add. Mss. 27820, ff. 20-22. 
romantic rhetorical style. He was a curous mixture of the political reformer and the psychological crank.

In large measure he is a good example of the type R. S. Neale has recently described as a "Middling Class" in an attempt to find a more flexible pattern of analysis for early nineteenth century social groups. ${ }^{1}$ He came from a professional family and received a reasonably good education. He enjoyed a standard of living above subsistence but he was propertyless and his means fluctuated widely with the changes in his circumstances. From an early age he challenged established authority, generally in terms of abstract rights and often because of abuses which did not affect him directly. His social identity depended upon his own achievements as a journalist and a politician and as such his position was unstable.

Beaumont managed to inspire confidence during two strikingly different periods in his life, first as a spokesman for colonial slavery in Jamaica and second as a leader of working class agitation in the Northeast. Between he was excoriated in Jamaica after the slave rebellion and ignored in London. His two periods of success corresponded to times when he could match his rhetorical talents and his personal qualities to policies that were widely demanded. It was his litigiousness and polemical style which initially attracted attention to him in Jamaica. Although he supported a variety of colonial reforms, he only came to grief when he broke with the predominant view on slavery. In England the pallid London reformers had no use for him, but the more restive northern districts found him right for their taste. Perhaps his most important achievement was the impetus he gave to working class radicalism there. His early death may have saved him from another reverse.

\footnotetext{
1 R. S. Neale, "Class and Class-Consciousness in Early Nineteenth Century England: Three Classes or Five?”, in: Victorian Studies, XII (1968-69), pp. 4-32.
} 